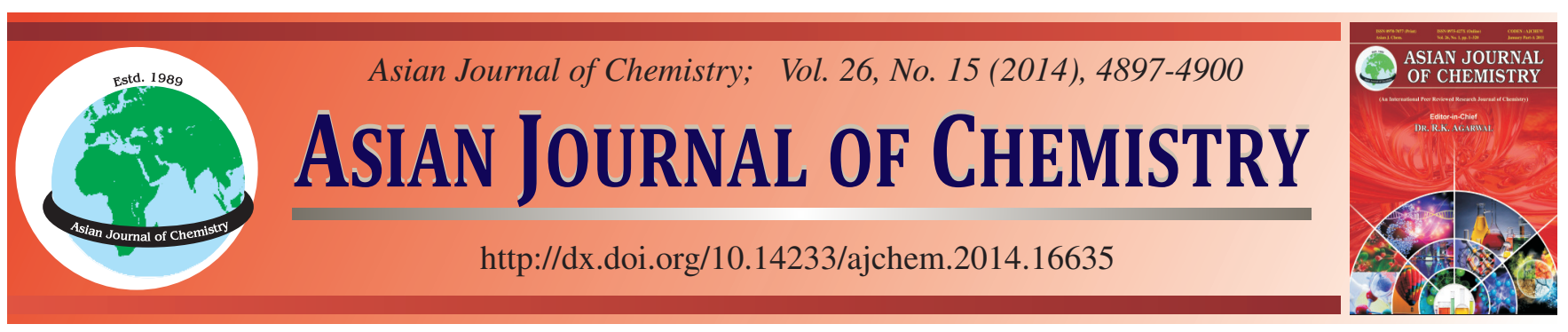

\title{
Discrepancy in Electrolytic Conductivity Value Using Different Concentrations of KCl (aq.) as Calibrating Standard
}

\author{
Hussein Hanibah, Nur Hasyareeda Hassan* and Azizan Ahmad
}

School of Chemical Sciences and Food Technology, Faculty of Science and Technology, Universiti Kebangsaan Malaysia, 43600 UKM Bangi, Selangor Darul Ehsan, Malaysia

*Corresponding author: E-mail: syareeda@ukm.edu.my

\begin{abstract}
Precise calibration of a conductivity probe in any conductance measurements is an important factor which determines the reliability of further analysis in an experiment. In normal practices standard solution of $\mathrm{KCl}$ (aq.) is used for an accurate calibration of the probe to determine the cell constant. Therefore, accurate measurements of electrical conductivity $(\kappa)$ for $\mathrm{LiClO}_{4}$ (aq.) at $25{ }^{\circ} \mathrm{C}$ are reported. A wide range of salt concentrations $10^{-3}-10^{-8} \mathrm{~mol} \mathrm{~cm}{ }^{-3}$ have been prepared through a series of dilutions from the stock solution used for the analysis. The conductivity measurement for $\mathrm{LiClO}_{4}$ (aq.) is carried out after the conductivity probe has been calibrated using different concentrations of primary standard $\mathrm{KCl}$ (aq.) at $25^{\circ} \mathrm{C}$ under a controlled environment. Since, the experimental conditions are same in both systems, the same cell constant is adopted in further calculations. The data is analyzed after Kohlrausch's equation and the limiting molar conductivity $\left(\mathrm{E}_{0}\right)$ values are determined at infinite dilution. It is experimentally shown that molar conductivity $(\mathrm{E})$ value for $\mathrm{LiClO}_{4}$ (aq.) at $25^{\circ} \mathrm{C}$ deviate from the regression function below the $\mathrm{E}$ value of the calibration standard used. This may suggest that the selection of the right concentrations of $\mathrm{KCl}$ (aq.) as a calibration standard is an important factor in liquid electrolyte system for a precise conductivity measurement. It is also noticed that the conductivity measurement of the analyte below the calibration value subjected to a large discrepancy in the conductivity measurement.
\end{abstract}

Keywords: Conductivity, Primary standard KCl (aq.), Kohlrausch's equation, Limiting molar conductivity, Liquid electrolyte.

\section{INTRODUCTION}

Electrical conductivity, $\kappa$ is one of the most intensively studied physical properties for different electrolyte systems ${ }^{1-3}$. Quantity $\kappa$ of an electrolyte solution is a measure of its ability to conduct electricity that very much depends on the number of ions presented. $\kappa$ is directly proportional to the total ions in the system. Therefore, it is normal to introduce the molar conductivity (E) as defined in eqn. 1 by dividing the electrolytic conductivity with the ionic concentration $(\mathrm{C})^{4}$.

$$
\mathrm{E}=\frac{\kappa}{\mathrm{C}}
$$

Quotient E as shown in eqn. 1 is normally expressed in siemens centimeter-squared per mole $\left(\mathrm{S} \mathrm{cm}^{2} \mathrm{~mol}^{-1}\right)$ and is used to analyse the properties of liquid electrolyte for instant measurement of the strength of solvent ${ }^{3}$, ion association ${ }^{5}$, individual ion mobility at a range of salt concentration $\left(\mathrm{C}_{\text {salt }}\right)$ at different analyte temperature ${ }^{6}$ and type of solvent used $^{7}$. Therefore, the molar conductivity of the analyte is inversely proportional to the total amount of ions that dissociate in the electrolyte system which greatly depends on the thermodynamic properties of the solvent used. Other than the ions concentration factor, this value is also considerably dependant on an accurate determination of the cell constant normally calculated after eqn. 2 .

$$
\kappa=\frac{1}{\mathrm{RA}}
$$

( $l$ l) length of electrode, cross-sectional surface area (A) of the electrode, $(\mathrm{R})$ electrical resistance of the solution. From eqn. 2 , the $/ / \mathrm{A}$ value is known as cell constant for the particular electrode.

Hence, in order to get a precise molar conductivity value a good estimation of the cell constant is important. In normal practice, the electrode used for conductivity measurement will be calibrated using a sample [typically an aqueous solution of potassium chloride, $\mathrm{KCl}(\mathrm{aq})$ ] of known conductivity and the cell constant is determined by a back calculation of eqn. 2 .

However, in any conductivity measurement it is important to precisely calibrate the conductivity probe used for the analysis. The purpose for this calibration is to determine the cell constant of the probe at a given temperature. The accuracy of the latter part of the conductivity measurement is determined by the right choice of the calibration standard to calibrate the probe. 
In a normal practice, different concentrations of primary standard aqueous potassium chloride, $\mathrm{KCl}$ (aq.) are used to calibrate the conductivity probe $\mathrm{e}^{8-10} \mathrm{KCl}$ (aq.), is chosen as a calibrating solvent because it is believed to act as a strong electrolyte that fully dissociates to its individual ions in aqueous medium ${ }^{8}$. $\mathrm{KCl}$ (aq.) is also noticed to fit well in the Kohlrausch's equation (eqn. 3) for a wide range of ion concentrations and temperature $^{4,8,11}$.

$$
\mathrm{E}=\mathrm{E}_{0}-\mathrm{KC}_{\text {salt }}^{1 / 2}
$$

Therefore, in this study, we have used different concentrations of primary standard $\mathrm{KCl}$ (aq.) to calibrate the probe used for the conductivity measurement and accurately determine the cell constant at $25^{\circ} \mathrm{C}$. Then, the validity range of the calibration using different concentrations of primary standard $\mathrm{KCl}$ (aq.) are tested for different electrolyte systems by calculating $\mathrm{E}$ and determining limiting molar conductivity, $\mathrm{E}_{0}$ value. Hence, aqueous lithium perchlorate, $\mathrm{LiClO}_{4}$ (aq.) at 25 $\pm 0.4{ }^{\circ} \mathrm{C}$ is chosen for this purpose and has been examined after Kohlrausch's equation (eqn. 3) at diluted salt concentrations, $\mathrm{C}_{\text {salt }}$. Later, the deviation of the molar conductivity values from eqn. 3 will be an indication of error in conductivity measurement that may be due to the calibration of the probe is no longer valid below that $\mathrm{C}_{\text {salt }}$.

\section{EXPERIMENTAL}

Anhydrous $\mathrm{LiClO}_{4}$ with purity $>99 \%$ was obtained from Acros Organic and dried in a vacuum oven at $100{ }^{\circ} \mathrm{C}$ for $24 \mathrm{~h}$ to eliminate any traces of water before dissolution in the water. Water is used for the preparation of $\mathrm{LiClO}_{4}$ (aq.) and the rinsing of the glassware in this analysis. The water used in this study was prepared by passing through the double distillated water to water deionizing system Arium ${ }^{\circledR}$ 611D1 (Sartorius, Goettingen, Germany) that generally has electrolytic conductivity less than $18 \times 10^{6} \Omega \mathrm{cm}$ at $25^{\circ} \mathrm{C}$. Afterwards, the deionized water was kept in a fluorinated high-density polyethylene (FLPE) container (Nalgene Labwere, Rochester USA) before further use.

Preparation of the $\mathrm{LiClO}_{4}$ (aq.) as well as the conductivity measurement for the systems was carried out under a controlled environment to minimise error in $\kappa$ measurements. The temperature of the laboratory was controlled at $25 \pm 2{ }^{\circ} \mathrm{C}$. All the glassware used was cleaned with concentrated chromic sulphuric acid. Then, it was further cleaned with Extran ${ }^{\circledR}$ detergent solution (Merck, Darmstadt, Germany) and rinsed with tap water and finally with deionized water. The glassware was dried in the conventional oven at $100{ }^{\circ} \mathrm{C}$ for $24 \mathrm{~h}$. The glassware was thermally equilibrated to the laboratory room temperature before use.

$\mathrm{LiClO}_{4}$ (aq.) stock solution of known concentration was prepared. Subsequently, the solution was stirred for $24 \mathrm{~h}$ at $50{ }^{\circ} \mathrm{C}$. Then, an approximately $8-12$ subsequent dilutions were carried out from the stock solution for the analysis. The $\kappa$ measurement for the diluted solution of $\mathrm{LiClO}_{4}$ (aq.) solutions were carried out using Mettler-Toledo SevenCompact S230 Conductivity meter (Schwerzenbach, Switzerland) with its diptype conductivity probes InLab ${ }^{\circledR} 731$ (measuring range 0.01$1,000 \mathrm{mS} \mathrm{cm}^{-1}$ ) and $\mathrm{InLab}^{\circledR} 741$ (measuring range 0.001-500 $\mu \mathrm{S} \mathrm{cm}^{-1}$ ). Both probes comprise of built-in temperature sensor with an accuracy of $\pm 0.4^{\circ} \mathrm{C}$. This conductivity meter has the feature of automatic temperature compensation. All the displayed $\kappa$ from the conductivity meter are the $\kappa$ at referred temperature of $25 \pm 0.4{ }^{\circ} \mathrm{C}$. All the preparation steps of the solution and conductivity measurements are carried out in a glove box under nitrogen gas condition avoid the absorption of carbon dioxide gas into the salt solution that may cause error in conductivity measurement particularly at low salt concentration.

The cell constant of InLab ${ }^{\circledR} 731$ and $\mathrm{InLab}^{\circledR} 741$ probes was estimated by automatic calibration on daily basis. The primary standard of aqueous solution of potassium chloride (KCl) (Mettler-Toledo, Schwerzenbach, Switzerland) at concentrations $0.1,0.01$ and $0.0005 \mathrm{~mol} \mathrm{dm}^{-3}$ with the quantities $\kappa$ at $12.88,1413$ and $84 \mu \mathrm{S} \mathrm{cm}^{-1}$, respectively, at $25{ }^{\circ} \mathrm{C}$ were used for the calibration with the conductivity meter attached to InLab ${ }^{\circledR} 731$ and InLab ${ }^{\circledR} 741$, respectively.

\section{RESULTS AND DISCUSSION}

Lithium perchlorate $\left(\mathrm{LiClO}_{4}\right)$ salt is believed to act as a strong electrolyte in the presence of water. Aqueous $\mathrm{LiClO}_{4}$ will completely dissociate to its individual ions (cation and anion) especially at a much diluted $\mathrm{C}_{\text {salt }}$ as shown in eqn. $4^{12,13}$.

$$
\mathrm{LiClO}_{4}(\mathrm{~s}) \rightarrow \mathrm{Li}^{+} \text {(aq.) }+\mathrm{ClO}_{4}^{-} \text {(aq.) }
$$

As a result of their complete ionization, the concentration of ions in the solution is proportional to the concentration of $\mathrm{LiClO}_{4}(\mathrm{~s})$ added into the solvent. Kohlrausch suggested an empirical relationship as shown in eqn. 3. Therefore, this equation can be used to determine the validity of the conductivity measurement by comparing the molar conductivity value of the electrolyte system. Any discrepancy of this value from eqn. 3 may indicate error in the conductivity measurement.

Consequently, the validity of the conductivity measurements of aqueous $\mathrm{LiClO}_{4}$ using different concentrations of primary standard $\mathrm{KCl}$ as calibration standard was carried out at $25^{\circ} \mathrm{C}$ at a dilute range of $\mathrm{LiClO}_{4}$ (aq.) concentrations. Three different concentrations of $\mathrm{KCl}$ (aq.) solutions are used to calibrate the conductivity probe and the cell constant is determined accurately. Since, these measurements are performed in the same conductivity probe and in the same condition it is assumed that the value of cell constant remains unchanged for the two sets of measurements. Therefore, the validity of the conductivity measurements can be tested after eqn. 3 at a diluted concentration. $\mathrm{E}$ at infinite dilution, $\mathrm{E}_{0}$ can be estimated for a particular electrolyte system by extrapolation at $\mathrm{C}_{\text {salt }}^{1 / 2}=0$ of a plot of E versus $\mathrm{C}_{\text {salt }}^{1 / 2}$.

The $\kappa$ results for $\mathrm{LiClO}_{4}$ (aq.) solution were measured using conductivity meter coupled with $\mathrm{InLab}^{\circledR} 731$ and InLab ${ }^{\circledR}$ 741 at $25^{\circ} \mathrm{C}$ at $\mathrm{C}_{\text {salt }}=1 \cdot 10^{-3}-1 \cdot 10^{-8} \mathrm{~mol} \mathrm{~cm}{ }^{-3}$. Tables 1 and 2 show quantities of $\kappa$ and $\mathrm{E}$ at respective $\mathrm{C}_{\text {salt }}$ for $\mathrm{LiClO}_{4}$ (aq.) at $25^{\circ} \mathrm{C}$ for the work done in this study using different concentrations of $\mathrm{KCl}$ (aq.) as calibration standards.

Tables 1 and 2 quantities of $\kappa$ and $E$ at respective $C_{\text {salt }}$ for $\mathrm{LiClO}_{4}$ (aq.) at $25^{\circ} \mathrm{C}$ for the work done in this study using the method discussed above. Fig. 1 is plotted after eqn. 3 for set of data as tabulated in Tables 1 and 2 for aqueous solution of $\mathrm{LiClO}_{4}$ at $25{ }^{\circ} \mathrm{C}$ using different calibration standards. Only the highlighted data in Table- 1 and 2 was adopted for linear 
(a)
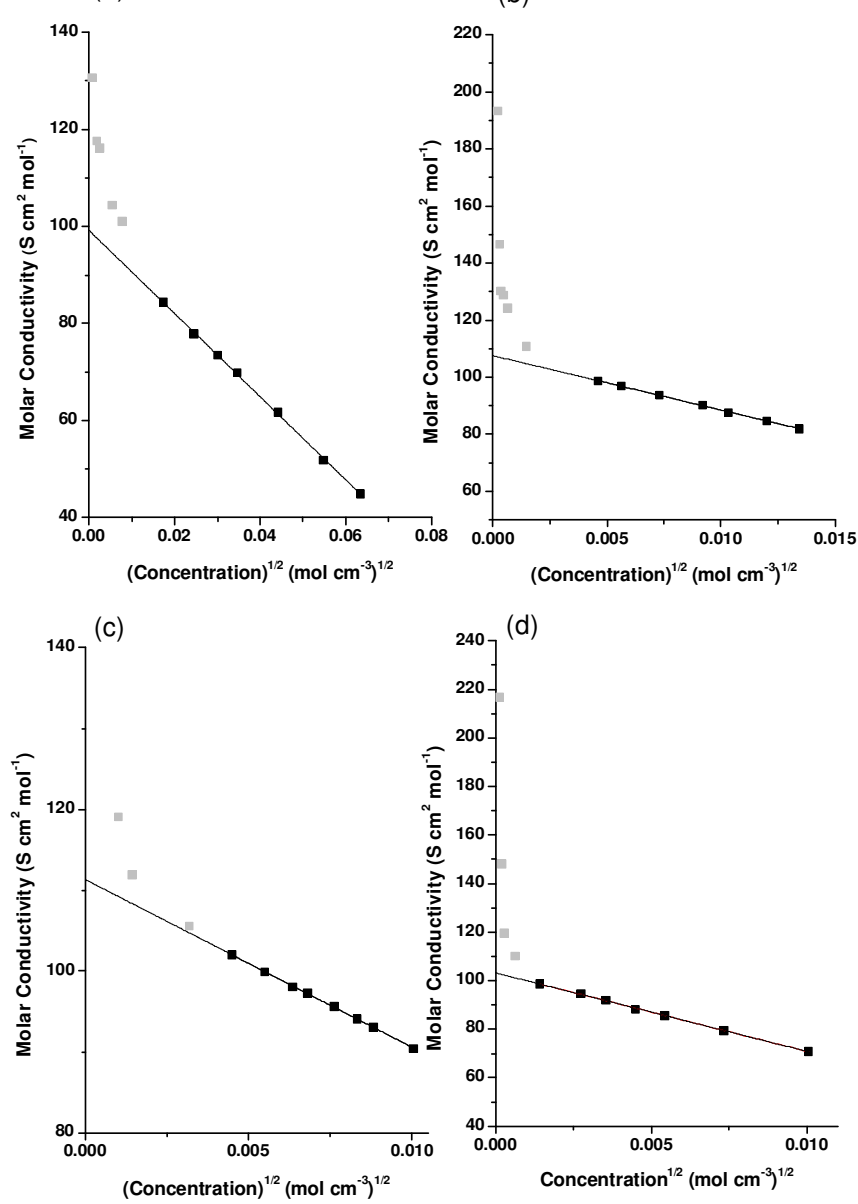

Fig. 1. Plotted after eqn. 3 for set of data as tabulated in Tables 1(a) and (b) and 2(c) and (d) for aqueous solution of $\mathrm{LiClO}_{4}$ at $25{ }^{\circ} \mathrm{C}$. Experiment data: (ロ) data included; ( $\square$ ) data excluded in the regression. Solid curve represents the linear regression after eqn. 3

regression of eqn. 3 in Fig. 1. Only $\kappa$ value of $\mathrm{LiClO}_{4}$ (aq.) above the $\kappa$ value of the calibration standard is used in this analysis. It was also noted the $\kappa$ values for $\mathrm{LiClO}_{4}$ (aq.) below $\kappa$ value of the calibration standard deviated from the linear approach after eqn. 3 and this data was excluded from the analysis.
Regression function from Fig. 1 after eqn. 3.

For (a):

$$
\begin{aligned}
\mathrm{E}= & \left(99.16 \mathrm{~S} \mathrm{~cm}^{2} \mathrm{~mol}^{-1}\right)-\left(856.5 \mathrm{~S} \mathrm{~cm}^{7 / 2} \mathrm{~mol}^{-3 / 2}\right)\left(\mathrm{C}_{\text {salt }}\right)^{1 / 2} \\
& (\text { correlation. } 0.9994)
\end{aligned}
$$

For (b):

$$
\begin{aligned}
& \mathrm{E}=\left(107.60 \mathrm{~S} \mathrm{~cm}^{2} \mathrm{~mol}^{-1}\right)-\left(1.90 \times 10^{3} \mathrm{~S} \mathrm{~cm}^{7 / 2} \mathrm{~mol}^{-3 / 2}\right)\left(\mathrm{C}_{\text {salt }}\right)^{1 / 2}(6) \\
& \quad \text { (correlation. 0.9995) }
\end{aligned}
$$

For (c):

$\mathrm{E}=\left(111.31 \mathrm{~S} \mathrm{~cm}^{2} \mathrm{~mol}^{-1}\right)-\left(2.07 \times 10^{3} \mathrm{~S} \mathrm{~cm}^{7 / 2} \mathrm{~mol}^{-3 / 2}\right)\left(\mathrm{C}_{\text {salt }}\right)^{1 / 2}(7)$ (correlation. 0.9997)

For $(\mathrm{d})$ :

$\mathrm{E}=\left(103.76 \mathrm{~S} \mathrm{~cm}^{2} \mathrm{~mol}^{-1}\right)-\left(3.33 \times 10^{3} \mathrm{~S} \mathrm{~cm}^{7 / 2} \mathrm{~mol}^{-3 / 2}\right)\left(\mathrm{C}_{\text {salt }}\right)^{1 / 2}(8)$ (correlation. 0.9991)

Fig. 1 indicates the regression analysis using eqns. 5-8 showing $\mathrm{E}_{0}$ values for $\mathrm{LiClO}_{4}$ (aq.) at $25{ }^{\circ} \mathrm{C}$ using different concentration of $\mathrm{KCl}$ (aq.). It is noticed that whenever the conductivity measurement of $\mathrm{LiClO}_{4}$ (aq.) is measured below the $\kappa$ value of the calibration standard used the molar conductivity data starts to deviate from eqn. 3 . This has been observed for all the studied systems using different concentrations of $\mathrm{KCl}$ (aq.).

This indicated a positive connection between the conductivity measurements of the sample with the standard used for the calibration for a particular probe. From the experimental data, it is noted the conductivity measurement below the conductivity data of the calibration standard resulted in a discrepancy in molar conductivity measurement which deviated from the ideal electrolyte behaviour even though all the conductivity measurements in this study were measured within the sensitivity of the probes used. This indicates that a careful selection of the $\mathrm{KCl}$ (aq.) solution for the calibration purpose is an important factor.

In addition, the validity of this set of experimental data was also confirmed by comparing the limiting molar conductivity value by extrapolating the $\mathrm{LiClO}_{4}$ (aq.) concentration to zero after eqn. 3 . In our opinion if the calibration is valid for a range of concentrations the $\mathrm{E}_{0}$ for $\mathrm{LiClO}_{4}$ (aq.) should be same

\begin{tabular}{|c|c|c|c|c|c|}
\hline \multicolumn{6}{|c|}{$\begin{array}{l}\text { TABLE-1 } \\
\text { ELECTROLYTIC CONDUCTIVITY ( } \kappa \text { ), MOLAR CONDUCTIVITY (E) AND C Calt FOR } \mathrm{LiClO}_{4} \text { (aq.) OF EXPERIMENTAL } \\
\text { RESULTS IN THIS STUDY USING DIFFERENT KCl (aq.) CALIBRATION STANDARD AT } 25^{\circ} \mathrm{C}\end{array}$} \\
\hline \multicolumn{3}{|c|}{$\begin{array}{c}\mathrm{InLab}^{\circledR} 731 \\
\text { Calibration standard: } 12.88 \mathrm{mS} \mathrm{cm}{ }^{-1} ; \text { Cell constant: } 0.551048 \mathrm{~cm}^{-1} \\
\end{array}$} & \multicolumn{3}{|c|}{$\begin{array}{c}\mathrm{InLab}^{\circledR} 731 \\
\text { Calibration standard: } 1413 \mu \mathrm{S} \mathrm{cm}^{-1} \text {; Cell constant: } 0.548753 \mathrm{~cm}^{-1}\end{array}$} \\
\hline $10^{4} \mathrm{C}_{\text {salt }}\left(\mathrm{mol} \mathrm{cm}^{-3}\right)$ & $10^{3} \kappa\left(\mathrm{S} \mathrm{cm}^{-1}\right)$ & $\mathrm{E}\left(\mathrm{S} \mathrm{cm}^{2} \mathrm{~mol}^{-1}\right)$ & $10^{4} \mathrm{C}_{\text {salt }}\left(\mathrm{mol} \mathrm{cm}^{-3}\right)$ & $10^{3} \kappa\left(\mathrm{S} \mathrm{cm}^{-1}\right)$ & $\mathrm{E}\left(\mathrm{S} \mathrm{cm}^{2} \mathrm{~mol}^{-1}\right)$ \\
\hline 40.2 & 188.4 & 44.861 & 1.81 & 14.88 & 81.976 \\
\hline 30.0 & 155.6 & 51.861 & 1.44 & 12.21 & 84.761 \\
\hline 19.5 & 122.6 & 61.735 & 1.06 & 9.330 & 87.680 \\
\hline 12.0 & 83.80 & 69.833 & 0.845 & 7.623 & 90.207 \\
\hline 9.00 & 66.10 & 73.444 & 0.532 & 4.984 & 93.687 \\
\hline 6.00 & 46.70 & 77.833 & 0.316 & 3.062 & 96.953 \\
\hline 3.00 & 25.30 & 84.333 & 0.213 & 2.100 & 98.675 \\
\hline 0.600 & 6.060 & 100.99 & 0.0213 & 0.2360 & 110.89 \\
\hline 0.300 & 3.130 & 104.32 & 0.00426 & 0.05290 & 124.28 \\
\hline 0.0600 & 0.6970 & 116.16 & 0.00213 & 0.02740 & 128.75 \\
\hline 0.0300 & 0.3530 & 117.66 & 0.00128 & 0.01663 & 130.24 \\
\hline 0.00600 & 0.0784 & 130.65 & 0.000851 & 0.01248 & 146.60 \\
\hline- & - & - & 0.000426 & 0.008230 & 193.36 \\
\hline
\end{tabular}
as reported at similar experimental conditions.

Fig. 2 is plotted after eqn. 3 for the set of data as tabulated in Tables 1 and 2 for aqueous solution of $\mathrm{LiClO}_{4}$ at $25^{\circ} \mathrm{C}$. 
TABLE-2

ELECTROLYTIC CONDUCTIVITY ( $\kappa$ ), MOLAR CONDUCTIVITY (E) AND C salt $\mathrm{FOR} \mathrm{LiClO}_{4}$ (aq.) OF EXPERIMENTAL RESULTS IN THIS STUDY USING DIFFERENT KCl (aq.) CALIBRATION STANDARD AT $25^{\circ} \mathrm{C}$

\begin{tabular}{|c|c|c|c|c|c|}
\hline \multicolumn{3}{|c|}{$\begin{array}{c}\operatorname{InLab}^{\circledR} 731 \\
\text { Calibration standard: } 1413 \mu \mathrm{S} \mathrm{cm}^{-1} \text {; Cell constant: } 0.564230 \mathrm{~cm}^{-1}\end{array}$} & \multicolumn{3}{|c|}{$\begin{array}{c}\qquad \mathrm{InLab}^{\circledR} 741 \\
\text { Calibration standard: } 84 \mu \mathrm{S} \mathrm{cm}^{-1} \text {; Cell constant: } 0.094718 \mathrm{~cm}^{-1}\end{array}$} \\
\hline $10^{4} \mathrm{C}_{\text {salt }}\left(\mathrm{mol} \mathrm{cm}^{-3}\right)$ & $10^{3} \kappa\left(\mathrm{S} \mathrm{cm}^{-1}\right)$ & $\mathrm{E}\left(\mathrm{S} \mathrm{cm}^{2} \mathrm{~mol}^{-1}\right)$ & $10^{4} \mathrm{C}_{\text {salt }}\left(\mathrm{mol} \mathrm{cm}^{-3}\right)$ & $10^{3} \kappa\left(\mathrm{S} \mathrm{cm}^{-1}\right)$ & $\mathrm{E}\left(\mathrm{S} \mathrm{cm}^{2} \mathrm{~mol}^{-1}\right)$ \\
\hline 1.01 & 9.130 & 90.444 & 1.01 & 7.150 & 70.828 \\
\hline 0.780 & 7.258 & 93.092 & 0.539 & 4.273 & 79.318 \\
\hline 0.696 & 6.546 & 94.106 & 0.296 & 2.534 & 85.645 \\
\hline 0.581 & 5.551 & 95.597 & 0.202 & 1.781 & 88.172 \\
\hline 0.464 & 4.511 & 97.273 & 0.126 & 1.162 & 91.939 \\
\hline 0.404 & 4.960 & 98.060 & 0.0745 & 0.7056 & 94.669 \\
\hline 0.303 & 3.030 & 99.898 & 0.0202 & 0.1990 & 98.550 \\
\hline 0.202 & 2.060 & 102.03 & 0.00404 & 0.04450 & 110.20 \\
\hline 0.101 & 1.066 & 105.60 & 0.000806 & 0.009660 & 119.61 \\
\hline 0.0202 & 0.2260 & 111.94 & 0.000404 & 0.005980 & 148.09 \\
\hline 0.0101 & 0.1202 & 119.07 & 0.000162 & 0.003500 & 216.69 \\
\hline
\end{tabular}

However, only experimental data using InLab ${ }^{\circledR} 731$ with the calibration standard $1413 \mu \mathrm{S} \mathrm{cm}^{-1}$ is used and only this system match the expected experimental conditions from the expected value at $106 \mathrm{~S} \mathrm{~cm}^{2} \mathrm{~mol}^{-1}$ [Ref. 14].

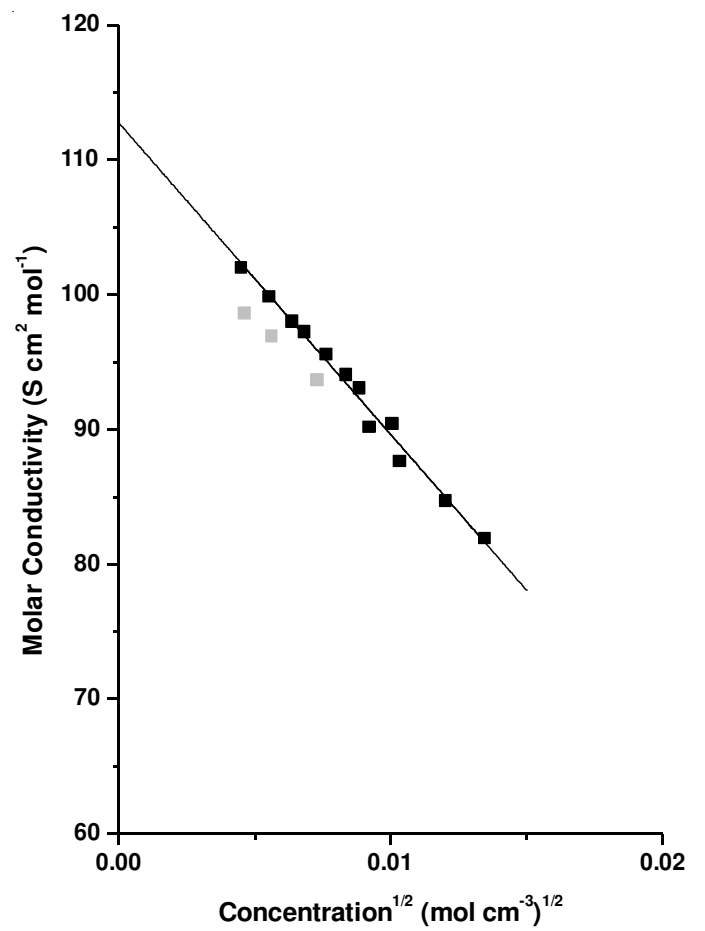

Fig. 2. Plotted after eqn. 3 for the set of data as tabulated in Table- 1 and 2 for aqueous solution of $\mathrm{LiClO}_{4}$ at $25{ }^{\circ} \mathrm{C}$. Experiment data: (口) data included (above the calibration standard value); ( $\mathbf{a}$ ) data excluded (below the calibration standard value) in the regression. Solid curve represents the linear regression after eqn. 3

Regression function for $\mathrm{LiClO}_{4}$ (aq.) in Fig. 2 reads:

$\left.\mathrm{E}=\left(112.77 \mathrm{~S} \mathrm{~cm}^{2} \mathrm{~mol}^{-1}\right)-\left(2.31 \times 10^{3} \mathrm{~S} \mathrm{~cm}^{7 / 2} \mathrm{~mol}^{-3 / 2}\right) \mathrm{C}_{\text {salt }}\right)^{1 / 2}(9)$ (correlation. 0.9852)

The $\mathrm{E}_{0}$ value after eqn. 9 obeys the expectant value for the same system at similar experimental conditions and the difference in limiting molar conductivity value from this study and ref. ${ }^{14}$ is less than $5 \%$. This agrees that the measurement of the electrolytic conductivity data in this study is reliable and can be suggested.

\section{Conclusion}

Accurate calibration of a conductivity probe for the determination of the cell constant is a predominant factor for an accurate conductivity measurement for the later part of the experiment. The conductivity measurement for an electrolyte system with a range of concentrations must be calibrated with appropriate calibration standards. Conductivity measurement below the calibration value of the primary standard $\mathrm{KCl}(\mathrm{aq})$ may cause deviation in the conductivity measurement from the real value even though the conductivity measurement is still within the range of the sensitivity of the probe used. As shown in this study, measurement of conductivity of $\mathrm{LiClO}_{4}$ (aq.) below the $\kappa$ value of the standard used causes a deviation in the measurement. This has been established after Kohlrausch's equation.

\section{ACKNOWLEDGEMENTS}

The authors are thankful to the Universiti Kebangsaan Malaysia for approving funds for this project via letters No. FRGS/1/2011, TK/UKM/02/39, NND/NM (2)/TD 11-046 and GGPM 2013-038.

\section{REFERENCES}

1. C.H. Chan and H.W. Kammer, J. Appl. Polym. Sci., 110, 424 (2008).

2. $\quad$ S.S. Sekhon, Bull. Mater. Sci., 26, 321 (2003).

3. E. Plichta, M. Salomon, S. Slane and M. Uchiyama, J. Solution Chem., 16, 225 (1987).

4. P.W. Atkins, Molecules in Motion, in Physical Chemistry, Oxford University Press, United States of America, edn 5, pp. 834-839 (1995).

5. D. Das, J. Solution Chem., 37, 947 (2008).

6. J. Barthel, R. Neueder, F. Feuerlein, F. Strasser and L. Iberl, J. Solution Chem., 12, 449 (1983).

7. H.M. Villullas and E.R. Gonzalez, J. Phys. Chem. B, 109, 9166 (2005).

8. Y.C. Wu and W.F. Koch, J. Solution Chem., 20, 391 (1991).

9. M. Tomsic, M. Bester-Rogac, A. Jamnik, R. Neueder and J. Barthel, J. Solution Chem., 31, 19 (2002).

10. G.T. Hefter and M. Salomon, J. Solution Chem., 23, 579 (1994).

11. K.J. Laidler, J.H. Meiser and B.C. Sanctuary, Solutions of Electrolytes, in Physical Chemistry, Houghton Mifflin Company, Boston, New York, edn 4, pp. 263-314 (2003).

12. J.F. Cote, G. Perron and J.E. Desnoyers, J. Solution Chem., 27, 707 (1998).

13. Y. Takeda, Y. Mochizuki, M. Tanaka, Y. Kudo, S. Katsuta and M. Ouchi, J. Incl. Phenom. Macrocycl. Chem., 33, 217 (1999).

14. D.R. Lide, Handbook of Chemistry and Physics, CRC Press Taylor \& Francis, edn 86 (2005). 